\title{
High Photocatalytic Activity under Visible Light for a New Morphology of $\mathrm{Bi}_{2} \mathrm{WO}_{6}$ Microcrystals
}

\author{
Willison Eduardo Oliveira Campos $1, * \mathbb{C}$, Francisco Xavier Nobre ${ }^{2}$, \\ Geraldo Narciso da Rocha Filho ${ }^{1}{ }^{10}$, Marcos Augusto Ribeiro da Silva ${ }^{3}$, \\ Carlos Emmerson Ferreira da Costa ${ }^{1,4}$, Luís Adriano Santos do Nascimento ${ }^{1,4}(\mathbb{D})$ and \\ José Roberto Zamian ${ }^{1}$ \\ 1 Laboratory of Catalysis and Oil Chemistry, postgraduate program in chemistry, Federal University do Pará, \\ Rua Augusto Corrêa, 66075-110 Belém-PA, Brazil \\ 2 Federal Institute of Education, Science and Technology of Amazonas, 69460-000 Coari-AM, Brazil \\ 3 Catalysis and Oil Chemistry Laboratory, Faculty of Chemistry, Federal University of Pará, \\ Augusto Corrêa Street, 66075-110 Belém-PA, Brazil \\ 4 Laboratory of Oils of the Amazon, Federal University of Pará, Science Park and Technology, \\ Perimetral Avenue, Guamá, 66075-750 Belé m-PA, Brazil \\ * Correspondence: willisoneduardo@gmail.com
}

Received: 20 June 2019; Accepted: 10 July 2019; Published: 5 August 2019

\begin{abstract}
In this work, a new morphology was obtained for bismuth tungstate $\left(\mathrm{Bi}_{2} \mathrm{WO}_{6}\right.$-glyc) using a hydrothermal method with the addition of glycerol as a surfactant. In order to compare, the bismuth tungstate without glycerol as the surfactant, i.e., $\mathrm{Bi}_{2} \mathrm{WO}_{6}$, was synthesized. Structural characterization by XRD and Rietveld refinement confirmed the orthorhombic structure as a single phase for all samples with high crystallinity. All active modes in Raman spectroscopy for the orthorhombic phase of bismuth tungstate were confirmed in agreement with XRD analysis. $\mathrm{N}_{2}$ adsorption/desorption and size pore distribution confirmed the high surface area $\left(85.7 \mathrm{~m}^{2} / \mathrm{g}\right)$ for $\mathrm{Bi}_{2} \mathrm{WO}_{6}$-glyc when compared with $\mathrm{Bi}_{2} \mathrm{WO}_{6}\left(8.5 \mathrm{~m}^{2} / \mathrm{g}\right)$. The optical band gap by diffuse reflectance was $2.78 \mathrm{eV}$ and $2.88 \mathrm{eV}$ for $\mathrm{Bi}_{2} \mathrm{WO}_{6}$-glyc and $\mathrm{Bi}_{2} \mathrm{WO}_{6}$, respectively. SEM images confirmed the different morphology for these materials, and microstructures with cheese crisp were observed for $\mathrm{Bi}_{2} \mathrm{WO}_{6}$-glyc (cheese crisp). On the other hand, flower-like microcrystals were confirmed for $\mathrm{Bi}_{2} \mathrm{WO}_{6}$ sample. The photocatalytic performance of $\mathrm{Bi}_{2} \mathrm{WO}_{6}$-glyc $(94.2 \%)$ in the photodegradation of rhodamine $\mathrm{B}(\mathrm{RhB})$ dye solutions at 60 min was more expressive than $\mathrm{Bi}_{2} \mathrm{WO}_{6}(81.3 \%)$ and photolysis $(8.2 \%)$ at $90 \mathrm{~min}$.
\end{abstract}

Keywords: glycerol; $\mathrm{Bi}_{2} \mathrm{WO}_{6}$; photocatalysis; organic dye

\section{Introduction}

In recent decades there has been reported an increase in wastewater containing organic pollutants and other compounds derived from industrial production and populations, which represent a risk due to their exhibiting high stability, carcinogenic effects and causing a decrease of oxygen gas in aquatic ecosystems [1]. Among these, organic textile dyes are commonly mentioned as the main compounds present in wastewater and are produced after industrial activity related to dyeing textile fibers, natural fibers, and paper; they are also stable to biodegradation processes [2]. Hence, the development of some methodologies for wastewater treatment have attracted significant attention around the world $[3,4]$. In this context, heterogeneous photocatalysis, in which it is possible to use solar energy as a source for oxidation/reduction reactions promoted after absorption of photons by photocatalysts in an aqueous medium, is considered an important option for wastewater treatment [1].

$\mathrm{TiO}_{2}$ is well-known as an efficient photocatalyst for application in the photodegradation of organic compounds and pathogens by redox processes. However, due to the large optical band gap of $\mathrm{TiO}_{2}$ 
$(3.2 \mathrm{eV})$, the excitation/recombination process for electrons is more effective when using ultraviolet radiation, which represents only $4 \%$ of solar light. Thus, the development of visible-light-driven photocatalysts have been studied for applications using solar energy $[5,6]$.

Bismuth tungstate $\left(\mathrm{Bi}_{2} \mathrm{WO}_{6}\right)$ is a member of the Aurivillius family $(\mathrm{n}=1)$, which has the general formula $\mathrm{Bi}_{2} \mathrm{~A}_{\mathrm{n}-1} \mathrm{~B}_{\mathrm{n}} \mathrm{O}_{3 \mathrm{n}+3}$ (where $\mathrm{A}=\mathrm{Ca}, \mathrm{Sr}, \mathrm{Ba}, \mathrm{Pb}, \mathrm{Bi}, \mathrm{Na}$, or $\mathrm{K}$ and $\mathrm{B}=\mathrm{Ti}, \mathrm{Nb}, \mathrm{Ta}, \mathrm{Mo}, \mathrm{W}$, or $\mathrm{Fe}$ ), and has also been described as a semiconductor prepared by a combination of layers alternately containing $\left(\mathrm{Bi}_{2} \mathrm{O}_{2}\right)^{2+}$ perovskite-like type and $\left(\mathrm{WO}_{4}\right)^{2-}$ ions. Due to its exhibiting excellent physical and chemical properties, including effective absorption of photons from the visible-light region, $\mathrm{Bi}_{2} \mathrm{WO}_{6}$ has attracted attention in photocatalytic applications [5-7].

The size and morphology of catalysts are important factors to be considered in photocatalytic performance [8]. Thus, the investigation of morphological aspects is frequently reported, mainly as a result of the effects promoted by surfactants [9]. Commonly, bismuth tungstate $\left(\mathrm{Bi}_{2} \mathrm{WO}_{6}\right)$ prepared by the hydrothermal method is associated with the formation of nanoplates linked to anisotropic growth along the (001) plane $[9,10]$.

In recent years, an impressive number of publications reporting the preparation of $\mathrm{Bi}_{2} \mathrm{WO}_{6}$ photocatalysts using different methods has arisen [11-13]. It is obvious that the strong electrostatic attraction of the $\mathrm{WO}_{4}{ }^{2+}$ and $\mathrm{Bi}^{3+}$ ions in aqueous solution may result in different morphologies of $\mathrm{Bi}_{2} \mathrm{WO}_{6}$ crystals according to the adjustment of the experimental conditions adopted [8]. Microspheres with a flower-like morphology have therefore been commonly reported using a template-free hydrothermal method [9]. Using the same method, Zhang et al. [14] have reported obtaining flower-like microspheres using the hydrothermal method in the absence of surfactants [14]. Moreover, Dai et al. [15] have acquired $\mathrm{Bi}_{2} \mathrm{WO}_{6}$ hollow sphere microcrystals using the hydrothermal route with addition of poly(vinylpyrrolidone) as a surfactant. Shang et al. [12] have obtained nanocage-like microcrystals for $\mathrm{Bi}_{2} \mathrm{WO}_{6}$ as a single morphology using carbon spheres.

In this work, we report an easy and fast way to obtain $\mathrm{Bi}_{2} \mathrm{WO}_{6}$ microcrystals with a new morphology using glycerol as a surfactant which has not until now been reported in the literature. Moreover, we evaluated the photocatalytic efficiency under simulated visible light using the photodegradation of Rhodamine B dye, as an application of water treatment.

\section{Results and Discussion}

\subsection{Crystallinity}

Figure 1a,c show the XRD patterns and Rietveld refinement plots of $\mathrm{Bi}_{2} \mathrm{WO}_{6}$ and $\mathrm{Bi}_{2} \mathrm{WO}_{6}$-glyc crystals synthesized by the hydrothermal method.

In Figure 1a, all diffraction peaks indexed indicate an orthorhombic structure with the space group Pca21 as the only crystallographic phase present for $\mathrm{Bi}_{2} \mathrm{WO}_{6}$ and $\mathrm{Bi}_{2} \mathrm{WO}_{6}$-glyc [16]. Moreover, these crystals have well-defined intensity and sharpness for planes (131), (002), (202), (331), (262), (400), (2102), (460), and (462), which indicate good crystallinity and structural order at short-range [17]. All diffraction peaks are consistent with the respective Inorganic Crystal Structure Database (ICSD) number 67647 and the literature [8,18-20].

Structural analysis by Rietveld refinement method for $\mathrm{Bi}_{2} \mathrm{WO}_{6}$ (Figure $1 \mathrm{~b}$ ) and $\mathrm{Bi}_{2} \mathrm{WO}_{6}$-glyc (Figure 1c) was performed using Fullprof software [21], which confirmed the orthorhombic structure as the only phase present. It is interesting to note that these crystals exhibit a high degree of crystallinity and purity without diffraction peaks associated with precursors or secondary phases. The excellent concordance of the experimental data with the crystallographic information contained in ICSD card number 67647 was confirmed by checking the residual line $\left(Y_{\text {obs }}-Y_{\text {cal }}\right)$ and $R$ parameters $\left(R_{p}, R_{w p}\right.$, $\mathrm{R}_{\text {exp }}$, and $\chi^{2}$ ), which suggest that these refinements are very available [22,23]. 


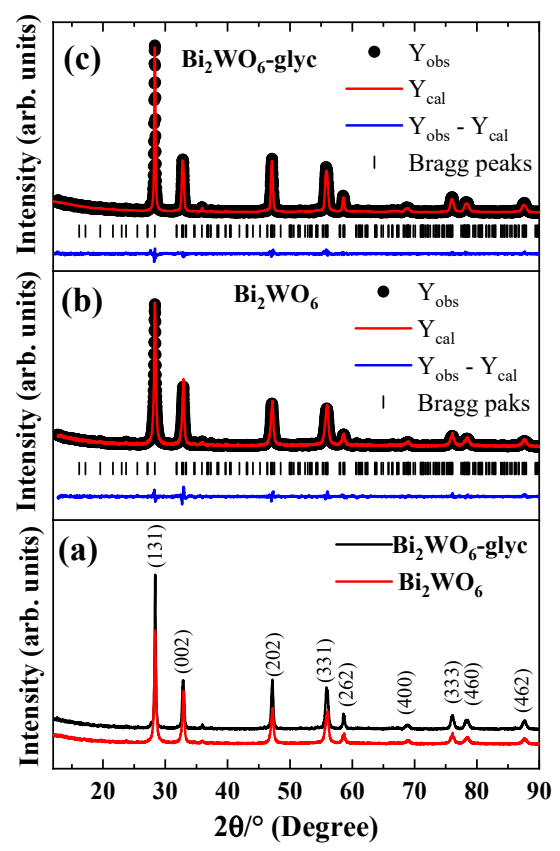

Figure 1. (a) $\mathrm{XRD}$ patterns of bismuth tungstate synthesized without $\left(\mathrm{Bi}_{2} \mathrm{WO}_{6}\right)$ and with the addition of $\left(\mathrm{Bi}_{2} \mathrm{WO}_{6}\right.$-glyc) glycerol, and Rietveld refinement plots for (b) $\mathrm{Bi}_{2} \mathrm{WO}_{6}$ and (c) $\mathrm{Bi}_{2} \mathrm{WO}_{6}$-glyc.

Table S1 (see supplementary electronic information) summarizes the Rietveld refinement results for the atomic position $(\mathrm{x}, \mathrm{y}$, and $\mathrm{z}$ ) of bismuth, tungsten, and oxygen atoms, as well as the occupation $\left(\mathrm{O}_{\mathrm{cc}}\right)$ and anisotropic thermal factors for $\mathrm{Bi}_{2} \mathrm{WO}_{6}$ and $\mathrm{Bi}_{2} \mathrm{WO}_{6}$-glyc. In this table, there are considerable variations in the atomic position for $\mathrm{Bi}, \mathrm{W}$, and $\mathrm{O}$ atoms from $\mathrm{Bi}_{2} \mathrm{WO}_{6}$ crystals when to compared of $\mathrm{Bi}_{2} \mathrm{WO}_{6}$-glyc crystals. This suggests that the addition of glycerol as a surfactant plays a role in the distortion of $\mathrm{Bi}-\mathrm{O}$ and $\mathrm{W}-\mathrm{O}$ bonds present in the $\left[\mathrm{BiO}_{6}\right]$ and $\left[\mathrm{WO}_{4}\right]$ clusters.

The average crystallite size $\left(D_{h k l}\right)$ for $\mathrm{Bi}_{2} \mathrm{WO}_{6}$ and $\mathrm{Bi}_{2} \mathrm{WO}_{6}-10$ was calculated using Debye-Scherrer's equation [16], $D_{h k l}=K \lambda / \beta \cos (\theta)$, where, $K$ is the shape factor $(K=0.9$, spherical shape), $\lambda$ is the wavelength of the $\mathrm{CuK} \alpha$ radiation, $\beta$ is the full width at half maximum (FWHM), and $\theta$ is the angle for each diffraction peak. In this study we used all the diffractions peaks contained in the XRD patterns for the $\mathrm{Bi}_{2} \mathrm{WO}_{6}$ and $\mathrm{Bi}_{2} \mathrm{WO}_{6}$-glyc crystals.

Table 1 presents the lattice parameters $(\mathrm{a}, \mathrm{b}$, and $\mathrm{c})$, direct cell volume $(\mathrm{V})$, crystallite size $\left(D_{h k l}\right)$, and for $\mathrm{Bi}_{2} \mathrm{WO}_{6}$ and $\mathrm{Bi}_{2} \mathrm{WO}_{6}$-glyc the Rietveld refinement results and values contained in ICSD card number 67647 and reported in the literature [12].

Table 1. Lattice parameters ( $a, b$, and c), direct unit cell volume, and crystallite size $\left(D_{h k l}\right)$ of $\mathrm{Bi}_{2} \mathrm{WO}_{6}$ and $\mathrm{Bi}_{2} \mathrm{WO}_{6}-10$ crystals and reported values by references.

\begin{tabular}{|c|c|c|c|c|c|c|}
\hline \multirow{2}{*}{ ID } & \multicolumn{3}{|c|}{ Lattice Parameters (̊̊) } & \multirow{2}{*}{$\mathrm{V}\left(\AA^{3}\right)$} & \multirow{2}{*}{$D_{h k l}(\mathrm{~nm})$} & \multirow{2}{*}{ Ref. } \\
\hline & $\mathbf{a}$ & $\mathbf{b}$ & c & & & \\
\hline $\mathrm{Bi}_{2} \mathrm{WO}_{6}$ & $5.443(3)$ & $16.428(1)$ & $5.451(2)$ & $487.45(8)$ & 24.761(78) & This work \\
\hline $\mathrm{Bi}_{2} \mathrm{WO}_{6}$-glyc & $5.437(1)$ & $16.433(4)$ & $5.457(9)$ & $487.66(4)$ & $20.153(80)$ & This work \\
\hline- & $5.437(3)$ & $16.430(2)$ & $5.458(4)$ & $487.63(3)$ & - & 2 \\
\hline- & 5.457 & 16.435 & 5.438 & 487.71(1) & 70 & [11] \\
\hline
\end{tabular}

Legend: ID = identification; $V$ = direct cell volume; $D_{h k l}=$ crystallite size; Ref. = reference; $\boldsymbol{\imath}$ = Inorganic Crystal Structure Database (ICSD) card number 67647.

The results show that all crystallographic parameters are in good agreement with those reported in the literature [12] and contained in ICSD card number 67647. Moreover, it was observed that the lattice parameters decreased with the addition of glycerol as the surfactant in the synthesis of $\mathrm{Bi}_{2} \mathrm{WO}_{6}$-glyc 
$(\mathrm{a}=5.437(1) \AA, \mathrm{b}=16.433(4) \AA$, and $\mathrm{c}=5.457(9) \AA$ ) when compared to the absence of this, which was represented by $\mathrm{Bi}_{2} \mathrm{WO}_{6}(\mathrm{a}=5.443(3) \AA, \mathrm{b}=16.428(1) \AA$, and $\mathrm{c}=5.451(2) \AA)$. In addition, there was a decrease in the direct cell volume and crystallite size from $487.66(4) \AA^{3}$ to $487.45(8) \AA^{3}$ and 20.153(80) $\mathrm{nm}$ to $24.761(78) \mathrm{nm}$, respectively.

Mishra et al. [24] have reported on the contribution of the addition of organic surfactant in the production of inorganic compounds, mainly in relation to the control of morphology, size, and velocity of the formation of nanocrystals. Therefore, the addition of glycerol in the synthesis of $\mathrm{Bi}_{2} \mathrm{WO}_{6}$-glyc promotes the increase of stability in the process of the creation of crystalline structures and the decrease of particle size.

\subsection{Spectroscopic Properties}

Group theory for bismuth tungstate with an orthorhombic structure and point group of symmetry $\mathrm{C}_{2 \mathrm{v}}$ confirm 105 vibrational modes in infrared and Raman spectroscopy which are represented by the irreducible representation $\Gamma_{(\mathrm{IR}+\mathrm{Raman})}=26 \mathrm{~A}_{1}+27 \mathrm{~A}_{2}+26 \mathrm{~B}_{1}+26 \mathrm{~B}_{2}$ [9]. However, the $A_{2}$ vibrational modes can be identified only in Raman spectroscopy, while $A_{1}, B_{1}$, and $B_{2}$ can be identified with both vibrational spectroscopies [16,20].

The experimental Raman spectra in the range from 85 to $1000 \mathrm{~cm}^{-1}$ and $[\mathrm{F}(\mathrm{R}) \mathrm{hv}]^{2}$ against a photon energy plot by uv-vis using the diffuse reflectance of $\mathrm{Bi}_{2} \mathrm{WO}_{6}$ and $\mathrm{Bi}_{2} \mathrm{WO}_{6}$-glyc crystals and the experimental Raman spectrum of glycerol are shown in Figure 2a,b.
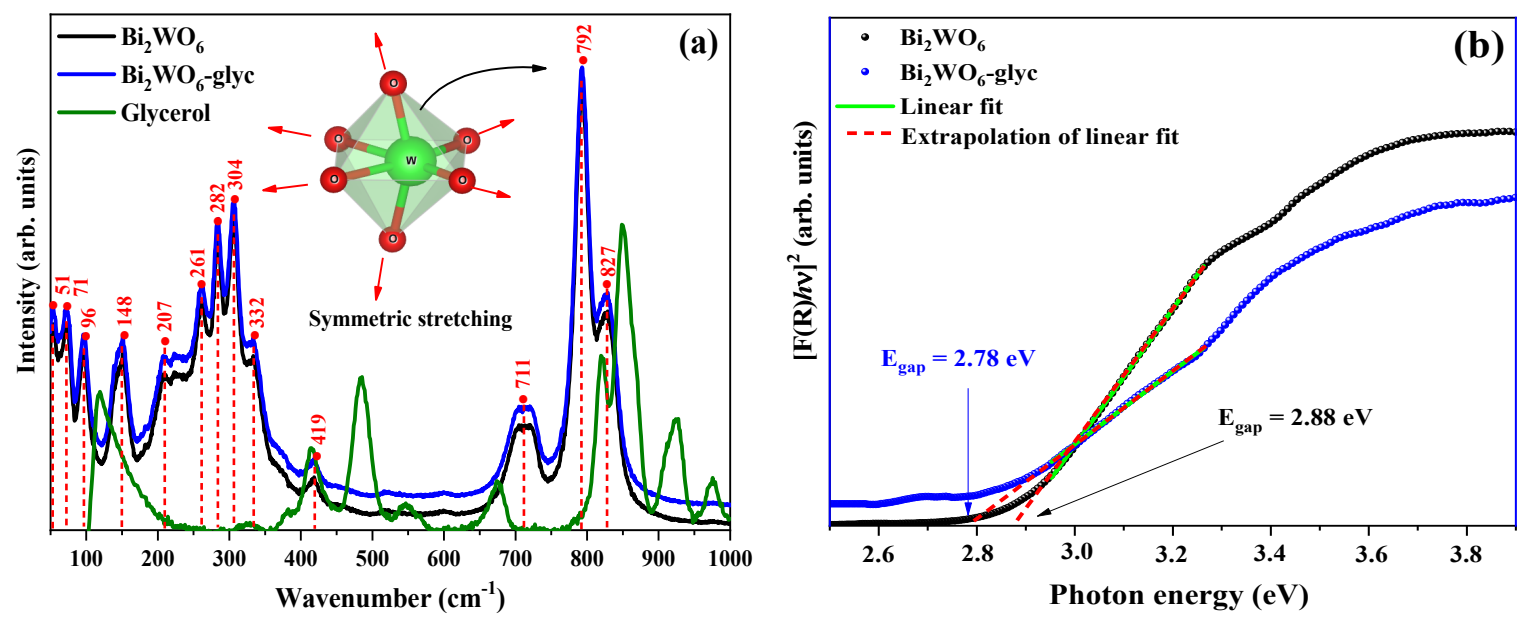

Figure 2. (a) Raman spectroscopy from 85 to $1000 \mathrm{~cm}^{-1}$ and (b) $[\mathrm{F}(\mathrm{R}) h v]^{2}$ versus photon energy from $\mathrm{UV}$-Vis by diffuse reflectance for $\mathrm{Bi}_{2} \mathrm{WO}_{6}$ and $\mathrm{Bi}_{2} \mathrm{WO}_{6}$-glyc and experimental Raman spectra of glycerol.

In Figure 2a, the experimental Raman spectra of $\mathrm{Bi}_{2} \mathrm{WO}_{6}$ and $\mathrm{Bi}_{2} \mathrm{WO}_{6}$-glyc exhibit a similar profile, suggesting that there were no active modes associated with the presence of the remaining glycerol, as can be seen when compared with the experimental Raman spectra of glycerol (Figure 2a) from the synthesis. Thus, all characteristic peaks of $\mathrm{Bi}_{2} \mathrm{WO}_{6}$ were identified as being in the range 85 to $1000 \mathrm{~cm}^{-1}$ [24]. The active modes at $792 \mathrm{~cm}^{-1}$ and $827 \mathrm{~cm}^{-1}$ are signatures of bismuth tungstate and may be attributed to the antisymmetric modes and symmetric modes of the O-W-O bonds present in the octahedral clusters [WO 6 ], respectively [16]. In $180 \mathrm{~cm}^{-1}, 230 \mathrm{~cm}^{-1}$, and $500 \mathrm{~cm}^{-1}$, it is possible to identify couplings of the active modes associated with distortions of the bonds present in the octahedra composed of tungsten and oxygen $\left(\mathrm{WO}_{6}\right)$ and in $332 \mathrm{~cm}^{-1}$ deltahedral clusters of bismuth and oxygen (Bi-O) $[20,24,25]$. The peak at $306 \mathrm{~cm}^{-1}$ is associated with the simultaneous translation movements of $\mathrm{Bi}^{3+}$ and $\mathrm{WO}_{6}{ }^{6-}$ along the crystal lattice $[16,24]$.

The optical band gap of $\mathrm{Bi}_{2} \mathrm{WO}_{6}$ and $\mathrm{Bi}_{2} \mathrm{WO}_{6}$-glyc was performed by UV-Vis using the diffuse reflectance spectra (Figure 2b). In this study, we adopted the Kubelka-Munk model [26,27], as 
represented by the equation $[\mathrm{F}(\mathrm{R}) h v]^{1 / \mathrm{n}}=\mathrm{C}_{1}\left(\mathrm{E}_{\text {gap }}-h v\right)$, where $\mathrm{F}(\mathrm{R})$ is the Kubelka-Munk function, $h v$ is the energy of a photon, and $C_{1}$ is the proportionality constant.

While $\mathrm{n}$ is the constant associated with different types of electronic transition, in this study direct allowed transitions $(n=0.5)$, which are associated with the electron transitions from hybrid $\mathrm{Bi} 6 \mathrm{~s}-\mathrm{O}$ $2 \mathrm{p}$ in the valence band (VB) to the $\mathrm{W} 5 \mathrm{~d}$ orbitals in the conduction band (CB), were considered [28]. The Egap values $2.88 \mathrm{eV}\left(\mathrm{Bi}_{2} \mathrm{WO}_{6}\right)$ and $2.78 \mathrm{eV}\left(\mathrm{Bi}_{2} \mathrm{WO}_{6}\right.$-glyc) were obtained via the plot of $[\mathrm{F}(\mathrm{R}) h v]^{2}$ against photon energy from the intercept of the tangent to the paraboloid curve.

The lesser value for the $\mathrm{E}_{\text {gap }}$ obtained for $\mathrm{Bi}_{2} \mathrm{WO}_{6}$-glyc indicates the presence of intermediate levels between the $\mathrm{VB}$ and $\mathrm{CB}$ associated with deformation of the $\mathrm{W}-\mathrm{O}$ and $\mathrm{Bi}-\mathrm{O}$ bonds in the $\left[\mathrm{BiO}_{6}\right]$ and $\left[\mathrm{WO}_{4}\right]$ clusters and oxygen vacancies, which was previously observed in the Rietveld refinement results. However, these values are in good agreement with the values reported in [29] and [28].

\subsection{Morphology of $\mathrm{Bi}_{2} \mathrm{WO}_{6}$ and $\mathrm{Bi}_{2} \mathrm{WO}_{6}$-glyc Microcrystals}

Figure $3 \mathrm{a}-\mathrm{c}$ show SEM images of $\mathrm{Bi}_{2} \mathrm{WO}_{6}$-glyc microcrystals with crispy cheese chip morphology. Moreover, the histograms for size diameter (Figure 3b) and size width (Figure 3c) measuring 100 microcrystals and adjusted by lognormal function [30] confirm that a significant percentage of microcrystals exhibited size diameter and size width in the ranges 1.1 to $1.5 \mu \mathrm{m}$ and 0.35 to $0.6 \mu \mathrm{m}$, respectively. It is interesting to note that this morphology has not been reported until now $[17,19,30,31]$. On the other hand, the $\mathrm{Bi}_{2} \mathrm{WO}_{6}$ microcrystals exhibit flower-like morphology (Figure 3d) $[17,30]$ with the majority percentage of microcrystals in the range 3 to $5 \mu \mathrm{m}$ for size diameter and 0 to $200 \mathrm{~nm}$ for size width.
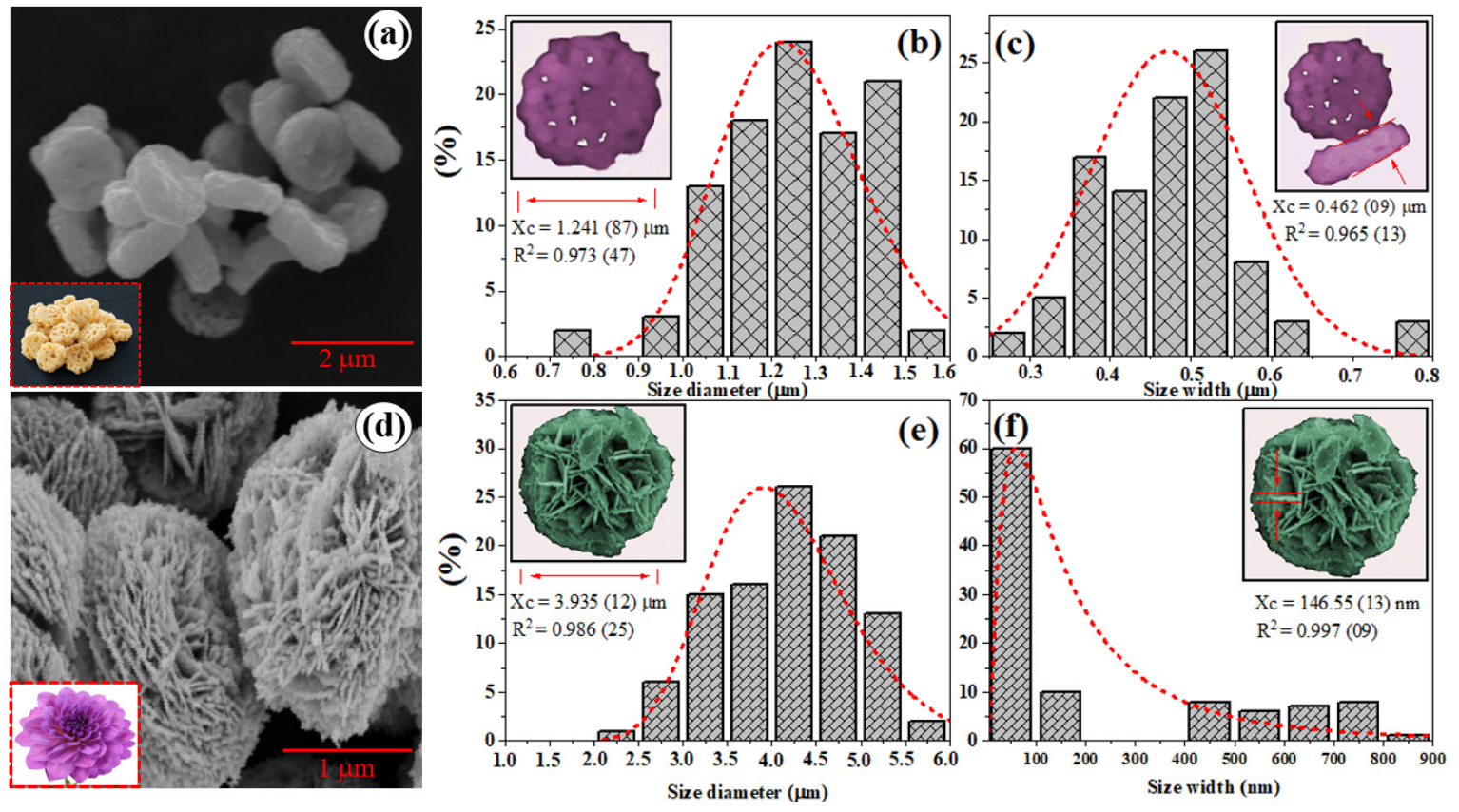

Figure 3. SEM images of (a) $\mathrm{Bi}_{2} \mathrm{WO}_{6}$-glyc and (d) $\mathrm{Bi}_{2} \mathrm{WO}_{6}$ and histograms for size diameter and size width for $\mathrm{Bi}_{2} \mathrm{WO}_{6}$-glyc $(\mathbf{b}, \mathbf{c})$ and $\mathrm{Bi}_{2} \mathrm{WO}_{6}(\mathbf{e}, \mathbf{f})$.

The behavior associated with the formation of $\mathrm{Bi}_{2} \mathrm{WO}_{6}$ microcrystals suggests that in the absence of surfactant, the obtention of nanoparticles was initiated by the strong electrostatic attraction between the $\mathrm{Bi}^{+3}$ and $\mathrm{WO}_{4}{ }^{-2}$ ions. In this case, nanoplates with size thickness of 146.55(13) nm (Figure 3f) were formed. In the second step, stable flower-like mesostructures (Figure 3e) were conducted by self-assembled nanoplates conducted by high temperature $\left(180^{\circ} \mathrm{C}\right)$ and pressure of the system.

Conversely, the reaction processed using the glycerol as a surfactant was carried out by the slow attraction of the $\mathrm{Bi}^{+3}$ and $\mathrm{WO}_{4}{ }^{-2}$ ions. There was therefore a slow and gradual formation of 
nanoparticles due to the increase in the viscosity of the aqueous medium by the addition of glycerol. The experimental results suggest that the obtention of crispy cheese chip morphology was initiated by the self-assembling effect of the nanoparticles, followed by compaction of these nanoparticles to disordered agglomerates with a high density of voids under pressure and temperature.

\subsection{Catalytic Performance}

The catalytic performance for the $\mathrm{Bi}_{2} \mathrm{WO}_{6}$ and $\mathrm{Bi}_{2} \mathrm{WO}_{6}$-glyc microcrystals under visible light in the photodegradation of rhodamine $\mathrm{B}(\mathrm{RhB})$ dye and photolysis is shown in Figure $4 \mathrm{a}-\mathrm{d}$. In order to evaluate the contribution of photolysis, within this process an experiment was performed with $\mathrm{RhB}$ dye solution under visible light (Figure 4a) without a catalyst for $90 \mathrm{~min}$. Therefore, a significant decrease in the maximum absorbance $\left(\lambda_{\max }=554 \mathrm{~nm}\right)$ characteristic of chromophore groups of $\mathrm{RhB}$ dye was not observed.
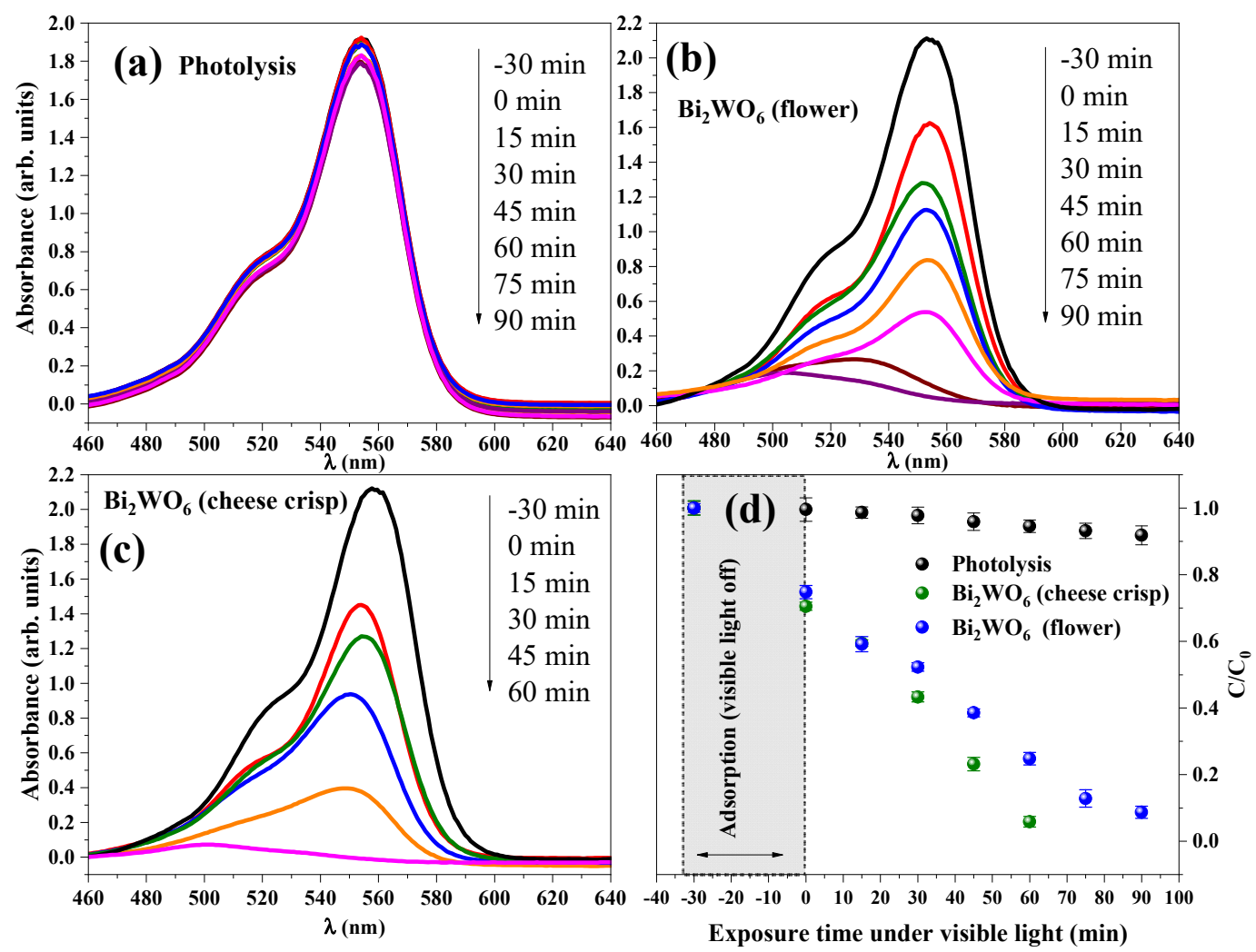

Figure 4. UV spectrum of RhB solution (a) photolysis, catalyzed by (b) $\mathrm{Bi}_{2} \mathrm{WO}_{6}$ and (c) $\mathrm{Bi}_{2} \mathrm{WO}_{6}$-glyc microcrystals and $(\mathbf{d})$ relative photodegradation $\mathrm{C} / \mathrm{C}_{0}$ against time (min).

Moreover, when experiments were carried out with the addition of $\mathrm{Bi}_{2} \mathrm{WO}_{6}$ (Figure $4 \mathrm{~b}$ ) or $\mathrm{Bi}_{2} \mathrm{WO}_{6}$-glyc microcrystals (Figure $4 \mathrm{c}$ ) in solution, a significant decrease was observed as a result of oxidation of the RhB molecules by oxidant species. In general, the hydroxyl radicals $\left(\mathrm{HO}^{\bullet}\right)$, holes $\left(\mathrm{h}^{+}\right)$, and superoxide radicals $\left(\mathrm{O}_{2}{ }^{-}\right)$, formed in the excitation/recombination process after absorption of a visible light photon by bismuth tungstate. However, the catalytic performance for $\mathrm{Bi}_{2} \mathrm{WO}_{6}$-glyc was more significant than compared with $\mathrm{Bi}_{2} \mathrm{WO}_{6}$ microcrystals, which in this case were associated with the lowest optical band gap $(2.75 \pm 01 \mathrm{eV})$, surface area, and morphology exhibited for the $\mathrm{Bi}_{2} \mathrm{WO}_{6}$ microcrystals.

Figure $4 \mathrm{~d}$ shows the relative degradation $\left(\mathrm{C} / \mathrm{C}_{0}\right)$ of $\mathrm{RhB}$ dye for all photocatalytic assays performed [30]. $\mathrm{C}_{0}$ and $\mathrm{C}$ are the initial concentration and the concentration at the desired reaction time, respectively. Thus, the first $30 \mathrm{~min}$ was carried out without visible light (only magnetic stirring) 
to obtain the adsorption equilibrium between the microcrystals and $\mathrm{RhB}$ dye molecules. It is important to note that the adsorption rates for $\mathrm{Bi}_{2} \mathrm{WO}_{6}$ and $\mathrm{Bi}_{2} \mathrm{WO}_{6}$-glyc were $25.2 \%$ and $29.4 \%$, respectively.

Table 2 summarizes the results for all catalytic assays performed with and without bismuth tungstate as the catalyst and the results reported in the literature for both materials. In this study, the pseudo first-order equation $\ln \left(C / C_{0}\right)=-k_{\text {obs }} t$, which is used in the Langmuir-Hinshelwood model [24] was applied for adjustment of experimental values and comprehension of catalytic behavior for each catalyst performed in the degradation of the RhB dye solution. In this equation, $-\mathrm{k}_{\mathrm{obs}}$ is the observed reaction rate constant and $t$ is the time.

Table 2. Optical band gap ( $\left.E_{\text {gap }}\right)$, degradation rate, observed reaction rate constant $\left(k_{\text {obs }}\right)$, half-life time $\left(t_{1 / 2}\right)$ for $\mathrm{Bi}_{2} \mathrm{WO}_{6}, \mathrm{Bi}_{2} \mathrm{WO}_{6}$-glyc, and photolysis, and some results reported in references under the photodegradation of RhB dye.

\begin{tabular}{cccccc}
\hline ID & Egap $_{\text {gaV) }}$ & $\begin{array}{c}\text { Degradation } \\
\mathbf{( \% )}\end{array}$ & $\begin{array}{c}\boldsymbol{k}_{\text {obs }} \times \mathbf{1 0}^{-\mathbf{3}} \\
\left(\mathbf{m i n}^{-\mathbf{1}} \mathbf{)}\right.\end{array}$ & $\mathbf{t}_{\mathbf{1} / \mathbf{2}}$ (min) & Ref. \\
\hline $\mathbf{B i}_{\mathbf{2}} \mathbf{W O}_{\mathbf{6}}$ & 2.88 & $81.3(3)$ & $22.68(02)$ & 30.56 & This work \\
$\mathbf{B i}_{\mathbf{2}} \mathbf{W O}_{\mathbf{6}}$-glyc & 2.78 & $94.2(8)$ & $55.89(01)$ & 12.40 & This work \\
$\mathbf{P h o t o l y s i s}$ & - & $8.2(5)$ & $4.54(09)$ & 152.67 & This work \\
$\mathbf{B i}_{\mathbf{2}} \mathbf{W O}_{\mathbf{6}}$ & 2.75 & - & 7.5 & 92.41 & {$[13]$} \\
$\mathbf{B i}_{\mathbf{2}} \mathbf{W O}_{\mathbf{6}}$ & - & - & 12 & 57.76 & {$[29]$} \\
\hline
\end{tabular}

Legend: ID = identification; $\mathrm{E}_{\text {gap }}=$ optical band gap; observed reaction rate constant $\left(k_{o b s}\right) ; \mathrm{t}_{1 / 2}=$ half-life time.

The degradation rates for $\mathrm{RhB}$ dye by photolysis and $\mathrm{Bi}_{2} \mathrm{WO}_{6}$ were $8.2 \%$ and $81.3 \%$, respectively, after $90 \mathrm{~min}$ under exposure to visible light. Ninety-four point two percent of the degradation rate of $\mathrm{RhB}$ dye solution was confirmed for $\mathrm{Bi}_{2} \mathrm{WO}_{6}$-glyc at 60 min under visible light. The high catalytic performance noted for the $\mathrm{Bi}_{2} \mathrm{WO}_{6}-10$ microcrystals was associated with a lower optical band gap $\left(E_{\text {gap }}=2.78 \mathrm{eV}\right)$, superficial area $\left(85.7 \mathrm{~m}^{2} / \mathrm{g}\right)$, the morphology of microcrystals, and the deformation of $\mathrm{Bi}-\mathrm{O}$ and $\mathrm{W}-\mathrm{O}$ bonds and oxygen vacancies in the structure, which was confirmed using structural analysis by XRD and Raman spectroscopy.

In order to obtain the $\mathrm{k}_{\mathrm{obs}}$ values for each catalytic assay, the $\ln \left(\mathrm{C} / \mathrm{C}_{0}\right)$ values were plotted against time, which resulted in 4.54(09) $\times 10^{-3} \mathrm{~min}^{-1}, 22.68(02) \times 10^{-3} \mathrm{~min}^{-1}$, and 55.89(01) $\times 10^{-3} \mathrm{~min}^{-1}$ for photolysis, $\mathrm{Bi}_{2} \mathrm{WO}_{6}$, and $\mathrm{Bi}_{2} \mathrm{WO}_{6}$-glyc, respectively. In addition, the lowest half-life time for $\mathrm{Bi}_{2} \mathrm{WO}_{6}$-glyc $\left(\mathrm{t}_{1 / 2}=12.40 \mathrm{~min}\right)$ confirms that these microcrystals exhibited a high catalytic profile when compared with reported values in the literature [31-36].

The mechanism for the oxidation process of organic molecules by oxidant species from the excitation/recombination processes in $\mathrm{Bi}_{2} \mathrm{WO}_{6}$ after the absorption of a photon has been reported in the literature $[13,15]$. In this study, the proposed mechanism was obtained by the initial absorption of a photon in visible light by the electrons present in the valence band associated with the small band gap value $\left(\mathrm{E}_{\text {gap }}=2.78 \mathrm{eV}\right)$ and high surface area $\left(85.7 \mathrm{~m}^{2} / \mathrm{g}\right)$. The water molecules adsorbed on the surface of $\mathrm{Bi}_{2} \mathrm{WO}_{6}$-glyc were oxidized by holes $\left(\mathrm{h}^{+}\right)$to hydroxyl radicals $(\mathrm{HO} \bullet)$ and cations $\left(\mathrm{H}^{+}\right)$. On the other hand, the electrons present in the conduction band were captured by the adsorbed oxygen molecules on the surface of $\mathrm{Bi}_{2} \mathrm{WO}_{6}$-glyc, which were reduced to superoxide radicals $\left(\mathrm{O}^{\circ}{ }^{-}\right)$[36]. These processes are demonstrated in the following equations:

$$
\begin{aligned}
& \mathrm{Bi}_{2} \mathrm{WO}_{6} \text {-glyc }+\mathrm{h} v \rightarrow \mathrm{Bi}_{2} \mathrm{WO}_{6}-\text { glyc }^{*}+\mathrm{h}^{+}{ }_{(\mathrm{VB})}+\mathrm{e}^{-}{ }_{(\mathrm{CB})} \\
& \mathrm{h}^{+}(\mathrm{VB}) . . \mathrm{H}_{2} \mathrm{O}_{\text {ads }} \rightarrow \mathrm{HO}^{\bullet}+\mathrm{H}^{+} \\
& \mathrm{e}^{-}{ }_{(\mathrm{CB})} . \mathrm{O}_{2 \text { ads }} \rightarrow \mathrm{O}_{2}{ }^{\cdot-} \\
& \mathrm{O}_{2}{ }^{--}+\mathrm{H}^{+} \rightarrow \mathrm{HO}_{2}^{-}
\end{aligned}
$$

The high oxidative potential of these species promoted the attack of the RhB dye strands that underwent deacetylation of the original molecule by breaking the bonds into lower molecular weight 
(CCO) colorless byproducts and the subsequent mineralization of these molecules into water molecules and carbon dioxide gases, oxygen, and carbon monoxide.

$$
\mathrm{O}_{2}{ }^{--}+\mathrm{HO}_{2}{ }^{-}+\mathrm{HO}^{\bullet}+\mathrm{RhB} \text { dye } \rightarrow \mathrm{CO}_{2}+\mathrm{H}_{2} \mathrm{O}+\mathrm{CCO}
$$

From Figure 4a it is possible to see that the degradations of RhB dye molecules also occurred under the action of visible light only; however, this occurred under a low conversion rate which explains the $8.2(5) \%$ degradation over 90 min exposure to visible light result. In addition, there was interaction of dye chains on the surface of the microcrystals, which underwent the degradation by the action of holes, a process which has been reported in the literature [37].

The reusability of $\mathrm{Bi}_{2} \mathrm{WO}_{6}$-glyc microcrystals (Figure $\mathrm{S1}$, see supplementary electronic information) in the photodegradation of $\mathrm{RhB}$ dye solution was performed over five consecutive photocatalytic runs. Thus, it was noted that the RhB dye solution was degraded at $90 \mathrm{~min}$ for all five runs and that these microcrystals were demonstrated to be stable and exhibiting high photocatalytic performance after all cycles.

\section{Materials and Methods}

\subsection{Synthesis of $\mathrm{Bi}_{2} \mathrm{WO}_{6}$}

Using a typical hydrothermal method [36], 0.9701g of $\mathrm{Bi}\left(\mathrm{NO}_{3}\right)_{3} \times 5 \mathrm{H}_{2} \mathrm{O}$ (Sigma-Aldrich, San Luis, MO, USA) was dispersed in $20 \mathrm{~mL}$ of distilled water under magnetic stirring for $15 \mathrm{~min}$. Then, $20 \mathrm{~mL}$ of an aqueous solution of $\mathrm{Na}_{2} \mathrm{WO}_{4} \times 2 \mathrm{H}_{2} \mathrm{O}(0.3218 \mathrm{~g})$ (Sigma-Aldrich, San Luis, MO, USA) was added. The mixture was stirred for another $15 \mathrm{~min}$ and transferred to a Teflon-lined autoclave which was kept heated at $170{ }^{\circ} \mathrm{C}$ for $24 \mathrm{~h}$. The product was collected by filtration, washed with distilled water and absolute ethanol several times, and then dried at $80^{\circ} \mathrm{C}$ in air and calcined at $550{ }^{\circ} \mathrm{C}$ for $4 \mathrm{~h}$.

\subsection{Obtention of $\mathrm{Bi}_{2} \mathrm{WO}_{6}$-glyc Microcrystals}

The synthesis was typically performed by dissolving $0.9708 \mathrm{~g}$ of $\mathrm{Bi}\left(\mathrm{NO}_{3}\right)_{3} \cdot \mathrm{xH}_{2} \mathrm{O}$ (Sigma-Aldrich, San Luis, MO, USA) into $20 \mathrm{~mL}$ of $\mathrm{HNO}_{3}$ (Synth) aqueous solution ( $50 \mathrm{mM}$ ) under magnetic stirring for $15 \mathrm{~min}$. Then, $0.3334 \mathrm{~g} \mathrm{Na} 2 \mathrm{WO}_{4} \cdot \mathrm{xH}_{2} \mathrm{O}$ (Sigma-Aldrich, San Luis, MO, USA) aqueous solution $(20 \mathrm{~mL})$ was added dropwise. After $15 \mathrm{~min}$ of stirring, $10 \mathrm{~mL}$ glycerol P.A. (Impex) was added to the suspension. The solution was transferred into a Teflon-lined autoclave and subjected to hydrothermal synthesis at $150{ }^{\circ} \mathrm{C}$ for $20 \mathrm{~h}$. The product was collected by filtration, washed with distilled water and ethanol several times, and dried at $80^{\circ} \mathrm{C}$ in air and calcined at $550{ }^{\circ} \mathrm{C}$ for $4 \mathrm{~h}$.

\subsection{Characterization}

The morphology was analyzed by scanning electron microscopy using a TESCAN model VEJA 3 SBU microscope with a voltage of $20 \mathrm{kV}$. X-ray diffraction was performed using a PANalytical PERT PRO MPD (PW 3040/60) diffractometer operating with CuK $\alpha(\lambda=1.5418 \AA)$ using the powder method. Structural refinement was performed using the free software Fullprof (June 2018 version) using the Pseudo-Voigt function and a six polynomial degree in the profile adjustment of the diffraction and background peaks, respectively.

UV-Vis spectra for each sample were recorded in the range of $200 \mathrm{~nm}$ to $900 \mathrm{~nm}$ using a Shimadzu spectrometer (model UV $2600 \mathrm{UV}$-Vis) under diffuse reflectance with $\mathrm{BaSO}_{4}$ as a reference. The surface area was determined using the Brunauer-Emmett-Teller (BET) method using a Micromeritics Instrument Corporation TriStar II model 3020 machine. Raman spectroscopy was performed with a Horiba (model T6400) spectrometer with line excitation at $514 \mathrm{~nm}$ with an $\mathrm{Ar}^{+}$laser and power of $20 \mathrm{~mW}$. 


\subsection{Photocatalytic Tests}

The photocatalytic activities of bismuth tungstate samples were evaluated by the degradation of $\mathrm{RhB}$ under simulated sunlight radiation using a $400 \mathrm{~W}$ metal vapor lamp with flow of 32,000 $\mathrm{lm}$ and efficiency of $80 \mathrm{~lm} / \mathrm{W}$ with intensity of irradiation, in w/ $\mathrm{m}^{2}$, through an ICEL SP-2000 solar intensity meter. A glass plate was used as an ultraviolet radiation filter.

In each experiment, $0.1 \mathrm{~g}$ of $\mathrm{Bi}_{2} \mathrm{WO}_{6}$ or $\mathrm{Bi}_{2} \mathrm{WO}_{6}$-glyc was added to $100 \mathrm{~mL}$ of $\mathrm{RhB}$ solution $(10 \mathrm{mg} / \mathrm{L})$. The suspensions were stirred in the dark for $30 \mathrm{~min}$ to obtain an adsorption-desorption equilibrium of the photocatalyst sample with RhB molecules. Subsequently, the solution was exposed to visible light irradiation under magnetic stirring with constant air flow. At regular time intervals, $3 \mathrm{~mL}$ aliquots were collected, centrifuged, and analyzed by maximal absorption $(553 \mathrm{~nm})$ in the UV-vis spectra of RhB using a thermo evolution array spectrophotometer. The degradation rate (D\%) was measured using the equation

$$
\text { Degradation (D) } \%=\left(C_{0}-C\right) / C_{0} \times 100 \%
$$

where $C_{0}$ is the initial concentration and $C$ is the concentration at a given time.

\section{Conclusions}

In summary, bismuth tungstate microcrystals $\left(\mathrm{Bi}_{2} \mathrm{WO}_{6}\right.$-glyc) photocatalysts were synthesized using the hydrothermal method with the addition of glycerol as a surfactant. XRD and Raman analysis confirmed the obtention of an orthorhombic phase with a high crystallinity degree. The morphology obtained for microcrystals was provided by compaction of nanocrystals initially directed by the glycerol effect, which created materials with a high surface area. The photocatalytic activity of catalysts was evaluated in photodegradation of rhodamine B dye, obtaining 94.2(8)\% degradation of RhB dye solution at $60 \mathrm{~min}$ under visible light. Thus, such photocatalysts possess great potential for application in water treatment.

Supplementary Materials: The following are available online at http://www.mdpi.com/2073-4344/9/8/667/s1, Figure S1: Photocatalytic degradation of $\mathrm{RhB}$ Dye using $\mathrm{Bi}_{2} \mathrm{WO}_{6}$-glyc microcrystals for five consecutive cycles, Table S1: Supplementary results from the Rietveld structural refinement for $\mathrm{Bi}_{2} \mathrm{WO}_{6}$ and $\mathrm{Bi}_{2} \mathrm{WO}_{6}$-glyc.

Author Contributions: Investigation, W.E.O.C.; methodology J.R.Z. and C.E.F.d.C.; project administration, G.N.d.R.F.; resources, L.A.S.d.N.; writing-original draft, F.X.N.; writing-review and editing, F.X.N. and M.A.R.d.S.

Funding: This research received no external funding other than through CAPES and CNPQ, Brazil.

Acknowledgments: The authors acknowledge CAPES/CNPQ which financed scholarships to carry out this work, the Laboratory of Catalysis and Oleochemistry (LCO), the Laboratory of Research and Analysis of Fuels (LAPAC), the Laboratory of Oils of the Amazon (LOA), all of which came from the Federal University of Pará (UFPA), the Federal Institute of Pará (IFPA), FINEP, the LABNANO-AMAZON/UFPA network for the support of the parties facilitated in this work, and Pro-rector of research and post-graduation (PROPESP/UFPA).

Conflicts of Interest: The authors declare no conflict of interest.

\section{References}

1. Dong, S.; Feng, J.; Fan, M.; Pi, Y.; Hu, L.; Han, X.; Liu, M.; Sun, J.; Sun, J. Recent developments in heterogeneous photocatalytic water treatment using visible light-responsive photocatalysts: A review. RSC Adv. 2015, 5, 14610-14630. [CrossRef]

2. Jo, W.-K.; Tayade, R.J. Recent developments in photocatalytic dye degradation upon irradiation with energy-efficient light emitting diodes. Chin. J. Catal. 2014, 35, 1781-1792. [CrossRef]

3. Santhosh, C.; Velmurugan, V.; Jacob, G.; Jeong, S.K.; Grace, A.N.; Bhatnagar, A. Role of nanomaterials in water treatment applications: A review. Chem. Eng. J. 2016, 306, 1116-1137. [CrossRef]

4. Yahya, N.; Aziz, F.; Jamaludin, N.A.; Mutalib, M.A.; Ismail, A.F.; Salleh, W.N.W.; Jaafar, F.; Yusof, N.; Ludin, N.A. A review of integrated photocatalyst adsorbents for wastewater treatment. J. Environ. Chem. Eng. 2018, 6, 7411-7425. [CrossRef] 
5. Zhang, L.; Wang, H.; Chen, Z.; Wong, P.K.; Liu, J. Bi $2 \mathrm{WO}_{6}$ micro/nano-structures: Synthesis, modifications and visible-light-driven photocatalytic applications. Appl. Catal. B Environ. 2011, 106, 1-13. [CrossRef]

6. Zhou, Y.X.; Tong, L.; Zeng, X.H.; Chen, X.B. Green synthesis of flower-like $\mathrm{Bi}_{2} \mathrm{WO}_{6}$ microspheres as a visible-light-driven photocatalyst. New J. Chem. 2014, 38, 1973-1979. [CrossRef]

7. Lin, X.; Liu, Z.; Guo, X.; Liu, C.; Zhai, H.; Wang, Q.; Chang, L. Controllable synthesis and photocatalytic activity of spherical, flower-like and nanofibrous bismuth tungstates. Mater. Sci. Eng. B 2014, 188, 35-42. [CrossRef]

8. Kadam, S.R.; Park, C.-J.; Kale, B.B.; Tamboli, M.S.; Sethi, Y.A.; Ambekar, J.D.; Nikam, L.K.; Panmand, R.P. Self-assembled hierarchical nanostructures of $\mathrm{Bi}_{2} \mathrm{WO}_{6}$ for hydrogen production and dye degradation under solar light. CrystEngComm 2014, 17, 107-115.

9. Zhang, L.; Zhu, Y. A review of controllable synthesis and enhancement of performances of bismuth tungstate visible-light-driven photocatalysts. Catal. Sci. Technol. 2012, 2, 694-706. [CrossRef]

10. Zhao, W.; Song, X.; Chen, G.; Tian, G.; Sun, S. Hydrothermal synthesis of $\mathrm{PbWO}_{4}$ uniform hierarchical microspheres. Mater. Lett. 2009, 63, 285-288. [CrossRef]

11. Chen, Z.; Qian, L.; Zhu, J.; Yuan, Y.; Qian, X. Controlled synthesis of hierarchical $\mathrm{Bi}_{2} \mathrm{WO}_{6}$ microspheres with improved visible-light-driven photocatalytic activity. CrystEngComm 2010, 12, 2100-2106. [CrossRef]

12. Shang, M.; Wang, W.; Xu, H. New $\mathrm{Bi}_{2} \mathrm{WO}_{6}$ Nanocages with High Visible-Light-Driven Photocatalytic Activities Prepared in Refluxing EG. Cryst. Growth Des. 2008, 9, 991-996. [CrossRef]

13. Photocatalysts, V.; Zhang, C.; Zhu, Y. Synthesis of Square $\mathrm{Bi}_{2} \mathrm{WO}_{6}$ Nanoplates as High-Activity Visible-Light-Driven Photocatalysts Chuan. Chemistry of Materials. 2005, 17, 3537-3545.

14. Chen, Z.; Wang, W.; Xu, H.; Zhang, L.; Zhu, W.; Zhou, L. Fabrication of flower-like $\mathrm{Bi}_{2} \mathrm{WO}_{6}$ superstructures as high performance visible-light driven photocatalysts. J. Mater. Chem. 2007, 17, 2526-2532.

15. Dai, X.J.; Luo, Y.S.; Zhang, W.D.; Fu, S.Y. Facile hydrothermal synthesis and photocatalytic activity of bismuth tungstate hierarchical hollow spheres with an ultrahigh surface area. Dalt. Trans. 2010, 39, 3426-3432. [CrossRef] [PubMed]

16. MacZka, M.; Hanuza, J.; Paraguassu, W.; Filho, A.G.S.; Freire, P.T.C.; Filho, J.M. Phonons in ferroelectric $\mathrm{Bi}_{2} \mathrm{WO}_{6}$ : Raman and infrared spectra and lattice dynamics. Appl. Phys. Lett. 2008, 92, 112911. [CrossRef]

17. Fan, J.; Wang, Y.; Zhao, Y.; Hu, X.; Liu, E. $\mathrm{Bi}_{2} \mathrm{WO}_{6}$ nanoflowers: An efficient visible light photocatalytic activity for ceftriaxone sodium degradation. Appl. Surf. Sci. 2017, 436, 854-864.

18. Xia, J.; Di, J.; Yin, S.; Xu, H.; Zhang, J.; Xu, Y.; Xu, L.; Li, H.; Ji, M. Facile fabrication of the visible-light-driven $\mathrm{Bi}_{2} \mathrm{WO}_{6} / \mathrm{BiOBr}$ composite with enhanced photocatalytic activity. RSC Adv. 2014, 4, 82-90. [CrossRef]

19. Xiao, L.; Lin, R.; Wang, J.; Cui, C.; Wang, J.; Li, Z. A novel hollow-hierarchical structured $\mathrm{Bi}_{2} \mathrm{WO}_{6} \mathrm{With}$ enhanced photocatalytic activity for $\mathrm{CO}_{2}$ photoreduction. J. Colloid Interface Sci. 2018, 523, 151-158. [CrossRef]

20. Kania, A.; Niewiadomski, A.; Kugel, G.E. Dielectric and Raman scattering studies of $\mathrm{Bi}_{2} \mathrm{WO}_{6}$ single crystals. Phase Trans. 2013, 86, 290-300. [CrossRef]

21. Fagundes, N.G.; Nobre, F.X.; Basilio, L.A.L.; Melo, A.D.; Bandeira, B.; Sales, J.C.C., Jr.; Andrade, J.C.S.; Anglada-Rivera, J.; Aguilera, L.; Pérez de la Cruz, J.; et al. Novel and simple way to synthesize Na2Ti6O13 nanoparticles by sonochemical method. Solid State Sci. 2019, 88, 63-66. [CrossRef]

22. Toby, B.H. R factors in Rietveld analysis: How good is good enough? Powder Diffr. 2006, 21, 67-70. [CrossRef]

23. Knight, K.S. The crystal structure of ferroelectric $\mathrm{Bi}_{2} \mathrm{WO}_{6}$ at $961 \mathrm{~K}$. Ferroelectrics 1993, 150, 319-330. [CrossRef]

24. Nobre, F.X.; Junior, W.A.G.P.; Ruiz, Y.L.; Bentes, V.L.I.; Silva-Moraes, M.O.; Silva, T.M.C.; Rocco, M.L.M.; González, D.R.L.; de Matos, J.M.E.; da Costa Couceiro, P.R.; et al. Facile synthesis of $\mathrm{nTiO}_{2}$ phase mixture: Characterization and catalytic performance. Material Research Buletin. 2019, 109, 60-71. [CrossRef]

25. Mishra, R.K.; Weibel, M.; Müller, T.; Heinz, H.; Flatta, R.J. Energy-effective Grinding of Inorganic Solids Using Organic Additives. CHIMIA Int. J. Chem. 2017, 71, 451-460. [CrossRef] [PubMed]

26. Maczka, M.; Paraguassu, W.; Filho, A.G.S.; Freire, P.T.C.; Filho, J.M.; Hanuza, J. Phonon-instability-driven phase transitions in ferroelectric $\mathrm{Bi}_{2} \mathrm{WO}_{6}: \mathrm{Eu}^{3+}$ : High-pressure Raman and photoluminescence studies. Phys. Rev. B-Condens. Matter Mater. Phys. 2008, 77, 094137. [CrossRef]

27. Džimbeg-Malčić, V.; Barbarić-Mikočević, Ž.; Itrić, K. Kubelka-Munk theory in describing optical properties of paper (I). Tehnicki Vjesnik. 2011, 18, 117-124.

28. Zhou, Y.; Zhang, Y.; Lin, M.; Long, J.; Zhang, Z.; Lin, H.; Wu, J.C.S.; Wang, X. Monolayered $\mathrm{Bi}_{2} \mathrm{WO}_{6}$ nanosheets mimicking heterojunction interface with open surfaces for photocatalysis. Nat. Commun. 2015, 6, 8340. [CrossRef] 
29. Amano, F.; Nogami, K.; Ohtani, B. Enhanced photocatalytic activity of bismuth-tungsten mixed oxides for oxidative decomposition of acetaldehyde under visible light irradiation. Catal. Commun. 2012, 20, 12-16. [CrossRef]

30. Phuruangrat, A.; Dumrongrojthanath, P.; Thongtem, S.; Thongtem, T. Hydrothermal synthesis of I-doped Bi2WO6 for using as a visible-light-driven photocatalyst. Mater. Lett. 2018, 224, 67-70. [CrossRef]

31. Li, H.; Zhou, Y.; Tu, W.; Ye, J.; Zou, Z. State-of-the-art progress in diverse heterostructured photocatalysts toward promoting photocatalytic performance. Adv. Funct. Mater. 2015, 25, 998-1013. [CrossRef]

32. Yuan, X.; Wang, H.; Chen, X.; Zhang, J.; Jiang, L.; Wu, Z.; Zeng, G.; Wang, H. Highly efficient photocatalysis toward tetracycline of nitrogen doped carbon quantum dots sensitized bismuth tungstate based on interfacial charge transfer. J. Colloid Interface Sci. 2017, 511, 296-306.

33. Sezancoski, J.C.; Bomio, M.D.R.; Cavalcante, L.S.; Joya, M.R.; Pizani, P.S.; Varela, J.A.; Longo, E.; Li, M.S.; Andrés, J.A. Morphology and blue photoluminescence emission of $\mathrm{PbMoO}_{4}$ processed in conventional hydrothermal. J. Phys. Chem. C 2009, 113, 5812-5822. [CrossRef]

34. Liu, Y.; Lv, H.; Hu, J.; Li, Z. Synthesis and characterization of $\mathrm{Bi}_{2} \mathrm{WO}_{6}$ nanoplates using egg white as a biotemplate through sol-gel method. Mater Lett. 2015, 139, 401-404. [CrossRef]

35. Zhang, X.; Gai, W. Effect of surfactant on the photocatalytic activity of $\mathrm{Bi}_{2} \mathrm{WO}_{6}$ nanoparticles. J. Mater. Sci. Mater. Electron. 2017, 28,9777-9781. [CrossRef]

36. Ge, M.; Liu, L. Sunlight-induced photocatalytic performance of $\mathrm{Bi}_{2} \mathrm{WO}_{6}$ hierarchical microspheres synthesized via a relatively green hydrothermal route. Mater. Sci. Semiconduct. Process. 2014, 25, 258-263. [CrossRef]

37. Regulska, E.; Breczko, J.; Basa, A. Pristine and Graphene-Quantum-Dots-Decorated Spinel Nickel Aluminate for Water Remediation from Dyes and Toxic Pollutants. Water 2019, 11, 953. [CrossRef]

(C) 2019 by the authors. Licensee MDPI, Basel, Switzerland. This article is an open access article distributed under the terms and conditions of the Creative Commons Attribution (CC BY) license (http://creativecommons.org/licenses/by/4.0/). 